Ophthalmic Res. 1984;16:1-4

\title{
Contents, Vol. 16, No. 1-2, 1984
}

\section{Preface 5}

Single Retinal Neurons: Function and Structure

Studies on Visual Transduction in the Retinal Rods of the Frog

Baumann, $\mathrm{C} \quad 8$

Localization of ATPases in Retinal Receptor Cells

Ueno, S.; Umar, H.; Bambauer, H.-J.; Ueck, M

Amacrine Cells in Scotopic Vision

Nelson, R.; Kolb, H 21

A Chamber Preserving Cellular Function of the Isolated Rabbit Retina Suited for

Extracellular and Intracellular Recordings

Hanitzsch, R.; Tomita, T.; Wagner, H 27

Colour Vision: From Single Cells to Perception

Hering's Opponent Colour Channels Do Not Exist in the Primate Retinogeniculate Pathway

Gouras, P.; Eggers, H 31

Hypothesis Relating the Blue-Sensitive Cone Mechanism to Surround Excitation of

Primate Retinal Off-Centre Neurones

Krüger, J.; Zrenner, E 36

Cone Mechanisms and Their Colour-Opponent Interaction in Monkey and Cat

Wienrich, M.; Zrenner, E 40

Spectral Sensitivity of the European Ground Squirrel (Citellus citellus L.)

Eigner, D.; Wündsch, L.; Lützow-Kafka, A. v 48

Visual Thresholds in the Deutan Type of Red-Green Deficient Colour Vision

Aaltonen, H.; Aarnisalo, E.; Elenius, V 54

Spatial Resolution, Determined by Electrical Potentials

Effect of Stimulus Intensity and Contrast on the Pattern ERG

Korth, M.; Rix, R 60

Pattern Reversal Responses in Man and Cat: A Comparison

Schuurmans, R.P.; Berninger, T

67

4 Contents

Equipotential Maps of Pattern-Evoked Potentials in Man

Adachi-Usami, E 73

Topical and Temporal Aspects of Cortical Responses to Pattern Reversal

Runge, J.; Sickel, W 80

Modulation Sensitivity and Functional Organization of the Receptive Field of Ganglion

Cells in the Pigeon (Columba livia)

Pak, M.A 85

Extraocular Light Reception: Structure

Evolution of the Pineal Complex: Correlation of Structure and Function

Oksche, A 88 
Sensory and Central Nervous Elements in the Avian Pineal Organ

Korf, H.-W.; Vigh-Teichmann, 196

Cyclic Renewal of Whole Pineal Photoreceptor Outer Segments

Hartwig, H.-G 102

Extraocular Light Reception: Function

Circadian Information and Messages in the Modified Photoreceptor Cells of the Avian Pineal Organ: Retrospect and Prospect

Collin, J.P.;Juillard, M.T.; Voisin, P 107

Photosensory Properties of the Pineal Organ. Microiontophoretic Application of

Excitatory Amino Acids onto Pineal Neurons

Meissl, H.; George, S.R 114

Intracellular Dynamic Response Characteristics of Pineal Photoreceptors

Morita, Y.; Segi, K.; Samejima, M.; Nakamura, T 119

Photosensitivity and Biosynthesis of Indole Compounds in the Cells of the Receptor

Line of the Pineal Organ of the Pike

Falcon, J

123 